\title{
Relationship between Predictors of Employee Satisfaction and Employee Commitment in a Pharmaceutical Contract Research Organization
}

\author{
Sayoni Santra ${ }^{1}$, Dr. Pulak Mishra ${ }^{2}$ \\ ${ }^{1,2}$ Department of Humanities \& Social Science, Indian Institute of Technology-Kharagpur, India
}

\begin{abstract}
Retention is a biggest challenge as compare to hiring best talents and fairly described by the level of employee commitment and employee satisfaction. Both of these factors are very important for organizational success and share a favorable association however, it does not invariably signify that a satisfied employee is always being committed and thereby retain in the organization. The purpose of this research is aimed to provide a focus on the link between employee satisfaction on overall employee commitment in a Pharmaceutical Contact Research Organization based at Bangalore, India. In this study, employee commitment is viewed as the overall level of commitment including commitment to organization as well as to work and employee satisfaction is functioned by two broad constructs- organizational factors and personal characteristics, which further subdivided into nine predictors including organizational polices \& support, supervisor support, job characteristics, reward \& recognition, teamwork \& cooperation, feedback, maximizing potential and retention intension The study adopts a multiple regression model and results suggest that out of these nine predictors, only organizational support and reward \& recognition are significantly related to the organizational aspect of employee commitment (organization commitment), whereas the predictors like job characteristics and feedback have higher influence on work aspect of employee commitment (work commitment). Maximizing potential is only predictor which has significance on the overall level of employee commitment. On contrary, retention intension has an inverse relationship with the overall employee commitment indicating that the workforce is dominated by career oriented professionals having a tendency for opting better extrinsic opportunities thereby leading to organizational knowledge drain. The study tries to draw management attention on restructuring its existing strategies for maximizing the withholding capacity of talent pool which is absolutely vital for its competitive existence in global market.
\end{abstract}

Keywords: Employee satisfaction, employee commitment, organization commitment, work commitment, retention.

\section{INTRODUCTION}

The uninterested and unmotivated human resources leads to dissatisfaction and low commitment levels amongst employees which finally land up into possible consequences of unproductive trends including higher costs, business downturn and ultimately towards a negative effect on country's economy. Hence, it is necessary to maintain and sustain the most value-added assets, the existing workforce; with primarily requirement of making them satisfied. As satisfied and creative employees with loyal human resources are important organizational scoured, so with regard to employee's needs and how to replay them, it is needed to answer employee satisfaction and so to improve the level of employee commitment. Both commitment to organization and commitment to work assigned have potential effects on overall level of employee commitment, subsequently on organizational behavior and thereby predicting effectiveness of organization. Adopting a deliberate focus on overall employee commitment requires any organization to recognize and response the fundamental role that employees play in the success of organization. This includes thinking beyond the traditional emphasis on physical and investment capital and incorporating the value of "human capital" into calculation of success, especially for the development of knowledge economy.

In view of the above discussed, most vital and equally important aspects of organizational successemployee satisfaction and employee commitment, the purpose of this research is to find the links between these two. The trend in employee satisfaction raises concerns about the overall commitment amongst employees and ultimately influencing employee productivity, retention, creativity, risk-taking, mentoring, and altogether employee's motivation interest in work and personal growth as well. Typically, there are number of combination of factors that influence employee's decision to be satisfied thereby stay committed to job and organization. In this study, such contributing factors are termed as predictors of employee satisfaction that are established by review of literature.

As understanding the extend of employee commitment is critical in maximizing success of an organization thus, the value of the research lies with the quality of persisting human resources and 
management's orientation where it needs to recognize that its human resources have different reasons for working. The reasons for working are as individual as the person. But, they are doing work as to obtain something that eventually impacts their morale, motivation, and the quality of life which in turn may lead to better business performance in long run. The findings may be used as a step towards improving employee retention.

With respect to integrity of this research, previous researches have focused mainly on separated segments of employee satisfaction and employee commitment, particularly inclining towards the motivational theories, without making any directional or causal approach and reaching any practical conclusion or figure out possible strategies that could be used by any organization to balance different levels of commitment thereby enhancing the overall level of commitment amongst its employees. However, this research tries to be a connecting link between previous literature studies and works associated with employee satisfaction and employee commitment. Nevertheless a little past research has been done on impact of employee commitment on employee satisfaction role taking employee performance as moderating variable. But, the present study contradicts it and concurs on the reverse opinion that is, the influence of employee satisfaction on different levels of employee commitment which is considered as an outcome variable as it can be taken as more stable and sustainable measure as compare to employee satisfaction.

Since, the research is limited to participants employed in a pharmaceutical contact research organization in Bangalore, India; the result cannot be generalized to other occupational contexts and regions. Further research efforts are needed to obtain a better picture. Notwithstanding with this limitation, the overall findings of this research may add to the retention literature by highlighting how the employee satisfaction of individuals employed in a pharmaceutical contact research organization relates to their level of overall commitment. In practical terms, knowledge gained from observing the relationship between specific predictors of employee satisfaction and overall level of employee commitment of participants may be useful in other management activities including talent selection, placement and developmental activities of human resources.

\section{Employee Satisfaction:}

\section{CONCEPTUAL FRAMEWORK}

Employee satisfaction is the overall aspects of satisfaction of an employee working for an organization. Employee satisfaction is an important issue both for management and employees in any organizational setting and defined as how pleased an employee is with his or her position of employment along with the combination of affective reaction to their differential perceptions of what they want to receive compared with what actually they receive.(Cranny, Smith \& Stone 1992; Moyes, Shao \& Newsome 2008 ).In this environment for employee satisfaction, it is very essential to know which factors most affect employee satisfaction. The organizations want to spend good amount of time, money, and energy on programs, processes, and factors that will have a positive impact on employee satisfaction.

Through review of literature, the variables for employee satisfaction can mainly categorize into two levels as organizational variables and personal variables. The variables which highlight the organizational qualities experienced by an individual during his working tenure are termed as organizational variables. These organizational determinants of employee satisfaction play an important role as employees spend major part of their time in organization and hence, have a major influence on the level of job commitment and satisfaction level related to the attitude towards organization`s aims and objectives. In this study, eight facets of organization variables are taken into considerations which contribute effectively towards employee satisfaction. Another category includes the personal determinates that also help to maintain the motivation and personal factors of the work to work efficiently. Employee satisfaction can be associated with psychological factors and the factors taken into consideration which includes personality, age, education, gender differences and expectation. The details of each are discussed later in this paper.

This research helps management to establish the potential predictors of employee satisfaction which are actually influencing different(organization and work separately) along with the overall level of employee commitment(organization and work together) and also tries to bring attention towards the fact that why employee with adequate level of satisfaction leaves his/her organization

\section{A Conceptual Framework on Employee Commitment:}

No organization in today's competitive world can perform at peak levels unless each employee is committed to the organization's objectives and work as an effective member. And one of the challenges facing by modern organizations involves maintaining employee commitment in current business environment. To obtain the dimensionality of commitment, only those models that have generated the most research and best explained commitment in terms of organizational behavior are discussed here.

The best known three component conceptualization of organization commitment-A model developed by Meyer and Allen (1993) where commitment is defined as a psychological state that characteristics the employee's 
relationship with the organization and has implications for the decision to continue membership of it. These psychological states also have different implications for work relevant behavior.

These three approaches are referred as:

- Affective Commitment (Want to-): It refers to the employee's emotional attachment to, identification with, and involvement in the organization. Antecedes of affective commitment fall into four categories: Personal characteristics, job related characteristics, structural characteristics and work experiences.

- Continuance Commitment (Need to-): It refers to an awareness of the costs associated with leaving the organization. The potential costs of leaving an organization include the threats of wasting the time and effort spend acquiring non transferable skills, losing attractive benefits, giving up seniority-based privileges, or having to uproot family and disrupt personal relationship.

- Normative Commitment (Ought to-): It reflects a feeling of obligation to continue employment. Feeling of obligation to remain within an organization may result from internalization of normative pressure exerted on an individual prior to entry, or following entry. It may also develop when an organization provides the employee with reward in advance, or incurs significant costs in providing employment.

Employee commitment is defined as an individual's identification with and involvement in a particular organization. It is characteristics by a strong belief in and acceptance of organization`s goals and values, a willingness to exert considerable effort on its behalf, and a strong desire to maintain membership of it.

However, in the industrial era, employee satisfaction is not only considered important to the success of business, but this notion has now gained almost universal acceptance. Employee satisfaction is indeed important to business success, but if it were the only factor, satisfied employees would never leave the company, while dissatisfied employees would always do so. The theory of commitment is developed to answer question why satisfied employees leave, and dissatisfied employees stay (Hofmeyr \& Rice, 2000).Commitment often occurs in situations where personal needs and values are being violated. The conversion Model (Hofmeyr \& Rice 2000) has four aims, namely to identify what drives commitment in employees, to determine what makes employee highly committed and to drive retention programs by improving motivation, innovation and productivity. The fourfold classification gives rise to Employee Commitment Matrix which is given below.

\section{Exhibit 1- Employee Commitment Index}

\begin{tabular}{|c|c|c|}
\hline $\begin{array}{c}\text { COMMITMENT TO } \\
\text { TYPE OF WORK } \\
\text { HIGH }\end{array}$ & $\begin{array}{l}\text { Career Oriented } \\
\text { Employees are more focused on their career } \\
\text { development. } \\
\text { This may be highly productive, but also at risk } \\
\text { of being head-hunted. } \\
\text { Managers should explore ways to increase } \\
\text { company commitment. }\end{array}$ & $\begin{array}{l}\text { Ambassador } \\
\text { Employees who speak well of the Company and } \\
\text { are enthusiastic about their work. } \\
\text { These employees are assets and Managers should } \\
\text { use them and their Departments as models for } \\
\text { others. }\end{array}$ \\
\hline $\begin{array}{c}\text { COMMITMENT TO } \\
\text { TYPE OF WORK } \\
\text { LOW }\end{array}$ & $\begin{array}{l}\text { Uncommitted } \\
\text { Employees who are not enthusiastic about } \\
\text { their work or the Company they work for. } \\
\text { In the extreme uncommitted employees cause } \\
\text { dissent in their workplace. } \\
\text { Managers should find and fix issues resulting } \\
\text { in low commitment }\end{array}$ & $\begin{array}{l}\text { Company Oriented } \\
\text { Employees promote their Company but are } \\
\text { dissatisfied with or don't care about the work they } \\
\text { are doing. } \\
\text { This may impact on their performance. } \\
\text { These employees may be happier and more } \\
\text { committed in another position. }\end{array}$ \\
\hline & LOW COMMITMENT TO THE COMPANY & HIGH COMMITMENT TO THE COMPANY \\
\hline
\end{tabular}

\section{Source: Jamienson \& Richards, 1996}

The employee commitment index is a 4X4 matrix and on inter-matrix analysis, many crucial interpretations can be made regarding these four categories of employees. In an optimally productive organization, employees and organization have reciprocal obligations and mutual commitment, both stated and implied, that state their relationship. Those employees, who contribute most effectively on organizational performance, are the star performers and termed as ambassador. This category of highly engaged employees is sincerely associated with their own job performance along with the organization for which they are working. Their own career goals always synchronize with their organization's goals. They can move ahead to achieve best out of themselves for upliftment of organizational betterment. They are immensely motivated and serve as prominent business leaders and role models. But usually, they occupy a small fraction of work-force. Similarly, a smaller fraction of workforce consists of uncommitted category, includes those who are neither associated to their own job nor to their organization. They are isolated, demotivated and serve as liabilities to an organization. Mostly they are psychologically disengaged than physically. This category becomes a challenge for management when the fraction exceeds beyond a certain minimal level and thereby forces management to strategically investigate over the gaps that could cause problems in long run. 
The main focal points in this analysis are remaining two categories- Company oriented and career oriented. The company oriented includes those employees who are marginal performers and specifically affiliated with pay structures, organizational policies, facilities etc. Their association with their organization is of greater importance than their own job responsibilities. Alike ambassador, their career goals always synchronize with organizational goals but comparatively with low effectiveness. They may be important to an organization as they are capable of building image and branding name but as they are not potential productive performers hence, their dissociation would not cause any marked difference in organizational performance thereby organizational success. The career oriented includes those employees who are good performers. Their sincerity for their own job is much higher than the organization they are working with. In other words, their career goals are not entirely synchronizing with their organization's goal. However, by a part, some fraction of company orientation is innate in such employees as their collective good performances always benefit the organization. Their motivational orientations are function of situations. They are the opportunistic breed; they will remain in the organization as long as their career strategies align with organization. The day, they find further better scope, they take no time to leave. They are most critical segment of workforce. They can be the assets but also a major threat to management as their contribution enhances the business performance but their physiological dissociation can causes a great loss.

The present research observes the directional movement amongst these categories. Keeping two extremes constant, focus can be made on gradually developing career oriented category towards ambassador category by constantly identifying and upgrading those satisfaction factors which are influencing their affiliation towards organization hence equaling their overall level of commitment, thereby, ultimately transforming the good performers into star. Similarly, for those of company oriented, their level of performance can be raised and by focusing over those predictors of satisfaction which are associated with their work and job domains, thereby attempting to promote them from marginal performers to good performers in due course of time. Alignments between company's statements and management behavior is the key to enhance a context that evokes organizational commitment along with better career explorations which could lead to stability in overall level of employee commitment. Management and Human resources development agents should create a myriad of programs and projects to bolster the competencies, skills and morale throughout the organization in order to amplify overall level of employee engagement.

However, due to certain restriction in company's policies and practices, the participants provide very general responses about individual commitment level hence, it is difficult to differentiate the sample population exactly into different categories. So, the study continues with the overall employee commitment including both commitment for organization and work as well. Nonetheless, broadly some generalizations have been established in the conclusion part regarding counterbalancing different levels of commitment amongst the above cited categories of employees.

\section{ANALYTICAL FRAMEWORK}

An analytical model has been proposed after doing the literature review and it is tested by applying the regression to the study.

Exhibit 2 - Effect of Predictors of employee satisfaction on Employee Commitment

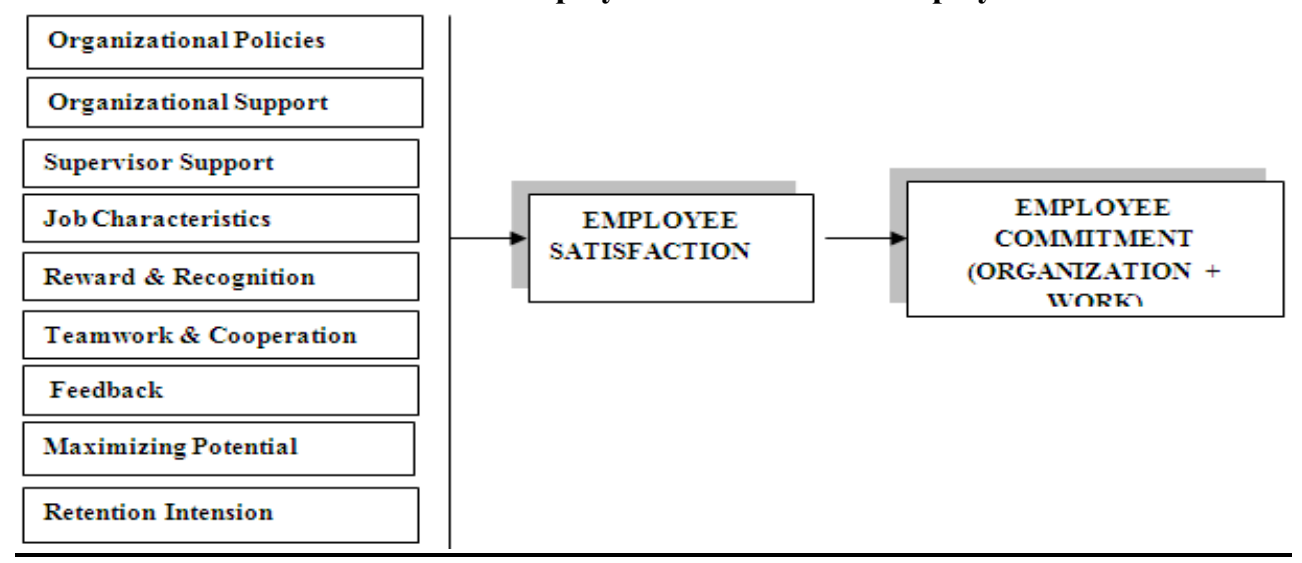

Organizational Policies-According to Locke (1976), there should be a clear policies and strategies in the organization which make easy for employees to understand their tasks and objectives etc. because otherwise, it may lead to dissatisfaction. Haisa (2009) demonstrated that the procedures of organization are important predictors of job satisfaction of employees and fair policies leads to employee satisfaction at work. 
Organizational support-Organization support is one of the most important organization concepts that keep employees in the organization. Therefore, organization support can be considered as a key factor in increasing the job satisfaction and commitment level of employees. Several studies showed that employees who get support by their organization are often satisfied.(Buchanen 1974; Tansky \& Cohen 2001; Riggle etal 2009)

Supervisor support-The predominant view has focused on the situational context i.e., supervisory support as a cause of satisfaction and has argued that high performance work practices and thus, positive working climate foster employee satisfaction.(Brown \& Ostroff 2004; Wright; Dunford \& Snell 2001; Gardner Moynihan \& Allen 2005)

Job characteristics-According to believe of some practitioners, the most imperative manipulate on staff satisfaction related to work is the nature of work itself, which is also called as intrinsic characteristics of work. Therefore, it is one of the critical factors of monetary executing life of an individual. Rosusseau(1978) had identified three components of employee satisfaction, in which job task factor is one of them.

Reward \& recognition- Flyn (1998) argued that reward \& recognition programs keep high spirits among employees, boost up their morale and create a linkage between performance and motivation of employees. The basic purpose of reward and recognition program is defined a system to pay and communicate it to the employees so that they can link their reward to their performance which ultimately leads to satisfaction.

Teamwork \& cooperation- Employees who feel a sense of teamwork and common purpose, a strong commitment to communication and managerial empowerment are most able and willing to deliver the result that customer expect.(Employee satisfaction-2005)

Feedback-A number of results have found a positive effect on satisfaction and performance at the motivational impact of goal-setting feedback in variety of situations. (Latham \& Kinne 1974; Klein \& Pachla 1973; Locke 1968). According to Payne and Hauty (1955) providing employees with feedback on performance can serve two functions-it can act as a directive to keep goal directed behavior on course and also, it can act as an incentive to stimulate greater effort amongst workers.

Maximizing potential- Introduction of copiousness programs that have been initiated in many organizations for providing a serene and constructive work circumstances so that job turnover rate could be minimized. Companies began realizing that they can challenge employees with lateral moves, skill development, job enrichment and especial assignments (Moses 1999). And the fundamentals of a good employee training program include orientation, soft skill training and technical skill training (Mel Kleiman 2000).

As discussed before personal determinates also that are related to psychological factors including personality, age, education, gender differences and expectation. In this study, keeping the first four factors constant as it would lead to higher degree of differentiation, only the fifth factor, i.e.; expectation is taken into consideration as "retention intension". Retention intension is an expectation of attachment to the job assigned and liking for the job assigned along with a liking for the organization. Brunner (1971) examined the reliability of reenlistment intension for forecasting actual reenlistment and found intentions to be closely and symmetrically related to behavior.

\section{Mathematical Model:}

For, bi-variate analysis we estimate the following regression model:

$$
\mathbf{Y}_{\mathrm{i}}=\boldsymbol{\alpha}+\boldsymbol{\beta} \mathbf{X}_{\mathrm{i}}+\boldsymbol{\mu}_{\mathrm{i}}
$$

Here, $\mathrm{Y}=$ Employee Commitment (with respect to work and company) and $\mathrm{X}=$ Antecedent of employee satisfaction.

For multivariate analysis we estimate the following regression model:

$$
\mathbf{Y}_{\mathrm{i}}=\boldsymbol{\beta}_{\mathrm{i}}+\sum \boldsymbol{\beta}_{\mathrm{j}} \mathbf{X}_{\mathrm{ji}}+\mathbf{v}_{\mathbf{i}}
$$

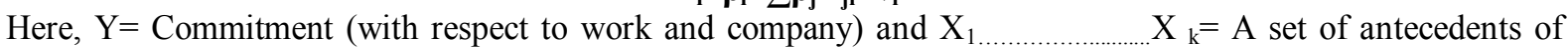
employee satisfaction.

Here, the commitment used as independent variables are selected on the basis of statistical significance of pairwise correlation coefficient.

Here, commitment to company signifies organizational commitment and commitment to work signifies work commitment.

\section{Methodology:}

A quantitative approach was followed administrating different types of questionnaire for measuring levels of employee satisfaction, commitment and effects of commitment. The questionnaire is subdivided into three scales for the measurement.

- Employee satisfaction scale: Developed by integrating various standards. It is used to capture overall aspects of employee satisfaction. (These items have been discussed under analysis in details) 
- Employee commitment: The measured instrument consists of Conversion Model questionnaire (Hofmeyr and Rice-2000).Despite of diversity of needs; this model has framed the employee commitment questionnaire aiming to determine the extent of employee commitment.

- Effects of employee commitment scale: It is a self constructed questionnaire which includes the effect of commitment with respect to work, employee himself self and organization respectively

This study adopted descriptive statistics, Pearson correlation coefficients, bi-variant and multivariate regression analysis to analyses the data for examining the influence of predictors of employee satisfaction on the overall employee commitment. The data was collected from primary and secondary sources.

The quantitative data was collected mainly through questionnaire which were tested on the stratified sample population of total 200 employees across the hierarchy. The respondent rate is $60 \%$. The mode of administration was by interacting and contacting the employees personally through mails. The secondary data was collected from books, magazines, research papers, internet, exit interview reports etc.

\section{Measurement:}

Employee Satisfaction: The scale consists of total 09 items with 40 statements and uses the five-point Likert type where, 1 signifies strongly agree, 2 signifies agree, 3 signifies neither agree nor disagree, 4 signifies disagree and 5 signifies strongly disagree.

The following items are taken as facets for employee satisfaction questionnaires:

\begin{tabular}{|l|l|}
\hline Items & Statements \\
\hline Organizational Policies & $\begin{array}{l}\text { Vision \& Mission (M\&V) Compensation \& Benefits (C\&B) Policies and procedures of } \\
\text { company (P\&P) }\end{array}$ \\
\hline Organizational Support & $\begin{array}{l}\text { Work/life balance (W-LB) Organizational advantage (OA) Organizational forgiveness } \\
\text { (OF) Organizational consideration on goals and values (G\&V) Organizational little } \\
\text { concern (OLC) Organizational care (OC) Organizational help in special favor (HSF) } \\
\text { Organizational help in problem (HIP) }\end{array}$ \\
\hline Job Characteristics & $\begin{array}{l}\text { Supervisor care about opinion (SC-Opn) Supervisor care about well being (SC-WB) } \\
\text { Supervisor consideration on goals and values (SC) Supervisor little concern (SLC) }\end{array}$ \\
\hline Reward \& Recognition & $\begin{array}{l}\text { Job infrastructure (JI) Job profile (JP) Work environment (WE) } \\
\text { (F\&O) Respect from the people work with (R) Praise from your supervisor (P) More } \\
\text { challenging work assignments (MWA) Public recognition (PUR) A reward /token of } \\
\text { appreciation (TK) }\end{array}$ \\
\hline Teamwork \& Cooperation & $\begin{array}{l}\text { Feels like everybody is on the same team at company (FST) Effective corporation (EC) } \\
\text { Strong spirit of teamwork and cooperation (TSE) }\end{array}$ \\
\hline Feedback & $\begin{array}{l}\text { Receiving useful and constructive feedback (RCF) Fair and appropriate employee } \\
\text { evaluation (F\&APE) Adequate feedback about performance (AFP) Receiving the praise } \\
\text { and recognition (RPR) }\end{array}$ \\
\hline Maximizing Potential & $\begin{array}{l}\text { Improving current job performance (OICJP) Expand/enhance the current job level (ECJ) } \\
\text { Career development programs (CDP) }\end{array}$ \\
\hline Retention Intension & $\begin{array}{l}\text { Apply for job within last 6 months (AJ) Intention to leave the company within 2 } \\
\text { years(getting opportunities from outside) (LC-OG) Intention to leave the company within } \\
\text { 2 years(getting no opportunities )(LC-NOG) }\end{array}$ \\
\hline
\end{tabular}

Conversion Model sample items are divided into three parts including:

- Commitment to company (Organizational commitment): It includes company rating, company comparison, wanting to work in the company and reason to work for the company.

(A 4 point ordinal scale variable where 1 signifies high commitment and 4 signifies low commitment.)

- Commitment to type of work (Work commitment): It includes rating the current work, work comparison, wanting to do the job and reasons to continue the same work.

(A 4 point ordinal scale variable where 1 signifies high commitment and 4 signifies low commitment.)

- Nine statements, which measure the possible motivational influence of employee commitment including remuneration package, relationship with supervisor/manager, proud about work achievements, content with recognition, work is valued, happy with responsibilities, satisfied with the chances of promotion, happy with the image of company, satisfied with working conditions.

The Conversion Model is selected as an instrument in this research owing to the fact that this model is a leading measure of commitment and focus on more than merely traditional loyalty and satisfaction. It is valid, reliable, and easy to use and understand and can be applied to any organization.

The questionnaire for effects of employee commitment consisting scales of 03 items with 04,05 and 06 statements for work, employee and organization respectively. 


\begin{tabular}{|l|l|}
\hline Items & Statements \\
\hline Work & $\begin{array}{l}\text { Improve the quality of the work, Contribute to more client centeredness, Influence the } \\
\text { productivity, Help to influence the other members of the team }\end{array}$ \\
\hline Employee & $\begin{array}{l}\text { Accept the willingness to change, Adapted to the changes that take place in the organization, } \\
\text { Learn more from the organization, Improve skills while staying within the organization, } \\
\text { Professionally growing in this organization }\end{array}$ \\
\hline Organization & $\begin{array}{l}\text { Improves communication, Generating new ideas, Knowledge and skills remain within the } \\
\text { organization, Improves the rate of delivery, Improves the internal mobility, Improves the } \\
\text { flexibility of work }\end{array}$ \\
\hline
\end{tabular}

\section{Descriptive Statistics:}

\section{Statistical Analysis}

Out of 200 questionnaires distributed, 120 are completed and hence used for analysis. Out of these respondents, $35 \%$ are female and $65 \%$ are male. Average age of sample is 30.5 years which implied that the population is comparatively young. Most of the respondents hold masters' degree and rest $\mathrm{PhD}$ and bachelors' .A majority of them have working experience between 5 to 7 years. In terms of marital status $72 \%$ are married, $26 \%$ are single and remaining $1 \%$ shared divorced status. From the frequency distribution of the predictors of employee satisfaction, it is observed that the professionals are content with the overall organizational policies of the company and a satisfactory interrelationship exists between the professionals with their respective supervisors. They are also happy with their job characteristics and possess a higher approach towards teamwork and cooperation. Although the professionals are might be content with their present job but simultaneously also have an intention to leave the organization on getting good openings. The organization has a good impact over the mind-set of the professionals as they avoid whistle blowing, thereby giving an implication that the professionals may be satisfied with the opportunities, facilities and working culture of the organization. From the frequency distribution of overall employee commitment, it is found that since "company is rated same as others", which in turn gives an indication that the percent of career oriented employees may be higher as compare to the rest categories (ambassador and company oriented). There exists a major proportion of workforce which is career conscious and orient towards external job markets for grabbing better opportunities. Rating of work is given as "above average", thus, it can be concluded that the work infrastructure and organizational working culture are adequately good thereby bringing on an impact of 'satisfaction' in the mindset of professionals. Similarly for effect of commitment on sample population, it is found that employee commitment has greater influence on the work performance and medium impact on employee himself and organization they are working with. This again conveys an impression of possessing a sizable segment of career oriented employees within the organization.

\section{Relational Statistics:}

Table-1 Correlation between Predictors of Employee Satisfaction and Employee Commitment

\begin{tabular}{|c|c|c|}
\hline Satisfaction Predictors & $\begin{array}{l}\text { Commitment to } \\
\text { Company(Organizational } \\
\text { Commitment) }\end{array}$ & $\begin{array}{l}\text { Commitment to Work } \\
\text { (Work Commitment) }\end{array}$ \\
\hline Organization Policies & $\begin{array}{l}0.5259 * * \\
(0.0000)\end{array}$ & $\begin{array}{l}0.3204 * \\
(0.0004)\end{array}$ \\
\hline Organizational Support & $\begin{array}{l}0.5599^{* *} \\
(0.0000)\end{array}$ & $\begin{array}{l}0.2936^{*} \\
(0.0011)\end{array}$ \\
\hline Supervisor`s Support & $\begin{array}{l}0.3733 * * \\
(0.0000)\end{array}$ & $\begin{array}{l}0.2634^{*} \\
(0.0037)\end{array}$ \\
\hline Job Characteristics & $\begin{array}{l}0.4310^{* *} \\
(0.0000)\end{array}$ & $\begin{array}{l}0.3555^{* *} \\
(0.0001)\end{array}$ \\
\hline Reward \& Recognition & $\begin{array}{l}0.3733^{* *} \\
(0.0000)\end{array}$ & $\begin{array}{l}0.1697 \\
(0.0638)\end{array}$ \\
\hline Teamwork \& Cooperation & $\begin{array}{l}0.3769^{* *} \\
(0.0000)\end{array}$ & $\begin{array}{l}0.2866^{*} \\
(0.0015)\end{array}$ \\
\hline Feedback & $\begin{array}{l}0.5283^{* *} \\
(0.0000)\end{array}$ & $\begin{array}{l}0.4196^{* *} \\
(0.0000)\end{array}$ \\
\hline Maximizing Potential & $\begin{array}{l}0.4952 * * \\
(0.0000)\end{array}$ & $\begin{array}{l}0.3928^{* *} \\
(0.0000)\end{array}$ \\
\hline Retention Intention & $\begin{array}{l}-0.3050^{*} \\
(0.0007)\end{array}$ & $\begin{array}{l}-0.3580^{* *} \\
(0.0001)\end{array}$ \\
\hline \multicolumn{3}{|c|}{$\begin{array}{l}\text { Note: } \\
\text { Table represents Pearson correlation coefficient along with Significant( } 2 \text {-tailed }) \\
\text { **Statistically significant at } 0.01 \text { level }(2 \text { tailed }) \\
\text { *Statistically significant at } 0.05 \text { level }(2 \text { tailed })\end{array}$} \\
\hline
\end{tabular}

Table-1 presents the pair-wise correlation coefficient and their statistical significance between predictors of employee satisfaction and overall employee commitment. 
It is observed that commitment with respect to company (organizational commitment)is positively correlated with organization policies, organizational support, supervisor's support, job characteristics, reward \& recognition, teamwork \& cooperation, feedback and maximizing potential and all the correlation coefficients are statistically significant at 1 percent level. For commitment with respect to work (work commitment), feedback and maximizing potential have positive impact at 1 percent significant level. Other like organization policies, organizational support, supervisor's support, job characteristics, and teamwork \& cooperation have positive significant influence at 5 percent significant level. Only reward \& recognition is significant at 10 percent level. But, it has been obtained that for both facets of employee commitment; retention intention has negatively significant influence at 1 percent level. Thus, it can be concluded that retention intention is the only predictor which is inversely associated with the overall employee commitment.

Table 2- Bi-Variable Regression Results

\begin{tabular}{|c|c|c|c|c|c|}
\hline Independent Variable & Coefficient & t-stat & Adjusted $\mathbf{R}^{2}$ & F-stat & No. of obs. \\
\hline \multicolumn{6}{|c|}{ Dependent Variable $\rightarrow$ Commitment wrt company (Syngene International) $=C_{C}$ Company (Organizational Commitment) } \\
\hline \multirow[t]{2}{*}{ Organizational Policies } & $2.49 \mathrm{E}-08(\mathrm{C})$ & \multirow{2}{*}{$7.03^{*}$} & \multirow{2}{*}{0.2766} & \multirow[b]{2}{*}{$49.37 *$} & \multirow[b]{2}{*}{120} \\
\hline & 0.5259177 & & & & \\
\hline \multirow[t]{2}{*}{ Organizational Support } & $6.24 \mathrm{E}-09(\mathrm{C})$ & \multirow[b]{2}{*}{$7.54 *$} & \multirow[b]{2}{*}{0.3134} & \multirow[b]{2}{*}{$56.79 *$} & \multirow[b]{2}{*}{120} \\
\hline & 0.559856 & & & & \\
\hline \multirow[t]{2}{*}{ Supervisor`s Support } & 4.45E-09(C) & \multirow[b]{2}{*}{$4.92 *$} & \multirow[b]{2}{*}{0.1393} & \multirow[b]{2}{*}{$24.25^{*}$} & \multirow[b]{2}{*}{120} \\
\hline & 0.3732607 & & & & \\
\hline \multirow[t]{2}{*}{ Job Characteristics } & $1.59 \mathrm{E}-08(\mathrm{C})$ & \multirow{2}{*}{$4.99 *$} & \multirow[b]{2}{*}{0.1857} & \multirow[b]{2}{*}{$24.94 *$} & \multirow[b]{2}{*}{120} \\
\hline & 0.4309782 & & & & \\
\hline \multirow[t]{2}{*}{ Reward \& Recognition } & $3.56 \mathrm{E}-09(\mathrm{C})$ & \multirow[b]{2}{*}{$4.48 *$} & \multirow[b]{2}{*}{0.1394} & \multirow[b]{2}{*}{$20.08 *$} & \multirow[b]{2}{*}{120} \\
\hline & 0.3733419 & & & & \\
\hline Teamwork \& Cooperation & $-2.21 \mathrm{E}-08(\mathrm{C})$ & & & & \\
\hline & 0.3768787 & $4.22 *$ & 0.142 & $17.84 *$ & 120 \\
\hline & $-2.78 \mathrm{E}-08(\mathrm{C})$ & & & & \\
\hline Feedback & 0.5283217 & $5.86^{*}$ & 0.2791 & $34.39^{*}$ & 120 \\
\hline Maximizing Potential & $-1.49 \mathrm{E}-08(\mathrm{C})$ & & & & \\
\hline & 0.495155 & $5.9^{*}$ & 0.2452 & $34.78^{*}$ & 120 \\
\hline Retention Intention & $-648 \mathrm{E}-09(\mathrm{C})$ & & & & \\
\hline & -0.3049609 & $-3.63 *$ & 0.093 & $13.14^{*}$ & 120 \\
\hline Dependent Variables $\rightarrow \mathrm{C}$ & wrt work (Wo & mitment) & & & \\
\hline Organization Policies & $-1.93 \mathrm{E}-08(\mathrm{C})$ & & & & \\
\hline & 0.3203891 & $3.47 *$ & 0.1026 & $12.06 *$ & 120 \\
\hline Organizational Support & $-3.09 \mathrm{E}-08(\mathrm{C})$ & & & & \\
\hline & 0.2936298 & $3.24^{*}$ & 0.0862 & $10.47^{*}$ & 120 \\
\hline Supervisor`s Support & $-3.18 \mathrm{E}-08(\mathrm{C})$ & & & & \\
\hline & 0.263353 & $2.52 * *$ & 0.0694 & $6.34^{*}$ & 120 \\
\hline Job Characteristics & $-2.23 \mathrm{E}-08(\mathrm{C})$ & $3.998 *$ & 01264 & $1589 *$ & 120 \\
\hline & 0.3554657 & & & & \\
\hline Reward\& Recognition & $-3.22 \mathrm{E}-08(\mathrm{C})$ & & & & \\
\hline & 0.1697259 & $3.68 *$ & 0.0288 & $3.68 *$ & 120 \\
\hline Teamwork\& Cooperation & $-5.20 \mathrm{E}-08(\mathrm{C})$ & & & & \\
\hline & 0.2866133 & $3.51 *$ & 0.9621 & $12.33^{*}$ & 120 \\
\hline Feedback & $-5.73-08(\mathrm{C})$ & & & & \\
\hline & 0.419615 & $4.9 *$ & 0.1761 & $23.98 *$ & 120 \\
\hline Maximizing Potential & $-4.71 \mathrm{E}-08(\mathrm{C})$ & & & & \\
\hline & 0.3927807 & $5.09 *$ & 0.1543 & $25.86^{*}$ & 120 \\
\hline Retention Intention & $-2.93 \mathrm{E}-08(\mathrm{C})$ & & & & \\
\hline & -0.3579968 & $-4.61 *$ & 0.1282 & $21.25 *$ & 120 \\
\hline $\begin{array}{l}\text { Values of t-stats have been } \\
* \text { Statistically significant at } \\
* * \text { Statistically significant a } \\
\text { C stands for Constant Valu }\end{array}$ & $\mathrm{m}$ respective in & & & & \\
\hline
\end{tabular}

Table-2 represents the results for the simple regression (bi-variate) models. As mentioned earlier, the selected independent variables are on the basis of statistically significance of pair-wise correlation coefficients between predictors of employee satisfaction and overall employee commitment.

From the given table, it has been obtained that on analyzing the individual coefficients of predictors of employee satisfaction on commitment with respect to company (organizational commitment), all the t-statistics appear to be statistically significant and positive expect retention intention which has statistically inverse 
influence on commitment with respect to company (organizational commitment) . F-statistics is statistically significant at 1 percent level for all predictors of employee satisfaction. Further, value of $\mathrm{R}^{2}$ is also reasonably decent for almost all the predictors. thereby inferring that all the predictors of employee satisfaction are statistically significant with good explanatory power. Thus, inferring that all the predictors of employee satisfaction individually have an equivalent and significant impact on organizational commitment.

Similarly, for commitment with respect to work (work commitment), all the t-statistics are appeared to be statistically significant at 1 percent level except supervisor support which is statistically significant at 5 percent. Similarly, all have positive influence except the retention intension, with F-statistics significant at 1 percent level. However, value of $\mathrm{R}^{2}$ is reasonably decent for most of the predictors except those of organizational support, supervisor support and reward \& recognition indicating their poor explanatory power. This infers that organizational policies, job characteristics, teamwork \& cooperation, feedback, maximizing potential and retention intension have greater influence on the work commitment as compare to remaining predictors.

From the above findings, it can be concluded that the predictors of employee satisfaction like organizational policies, job characteristics, teamwork \& cooperation, feedback and maximizing potential have greater positive influence on overall level of employee commitment overshadowing remaining predictors like organizational support, supervisor support and reward \& recognition. Retention intension is only predictor which has reciprocal relationship with overall employee commitment.

Table 3- Multi-Variable Regression Results

\begin{tabular}{|c|c|c|c|c|c|c|c|c|c|}
\hline \multirow{2}{*}{$\begin{array}{l}\text { Independent } \\
\text { Variable }\end{array}$} & \multirow{2}{*}{ Coefficient } & \multirow{2}{*}{$\begin{array}{c}\text { Robust Std. } \\
\text { Error }\end{array}$} & \multirow{2}{*}{$\mathbf{t}$} & \multirow{2}{*}{$\mathbf{P}>|\mathbf{t}|$} & \multicolumn{2}{|c|}{$\begin{array}{c}\text { Collinearly } \\
\text { Statistics }\end{array}$} & \multirow{2}{*}{$\begin{array}{l}\text { Beta } \\
\text { Value }\end{array}$} & \multirow{2}{*}{$\underset{\mathbf{R}^{2}}{\text { Adj- }}$} & \multirow{2}{*}{$\begin{array}{c}\text { F- } \\
\text { Stat }\end{array}$} \\
\hline & & & & & $\begin{array}{c}\text { Toleranc } \\
\text { e }\end{array}$ & VIF & & & \\
\hline \multicolumn{10}{|c|}{ Dependent Variable $\rightarrow$ Commitment wrt Company (Syngene International) $=C$ _Company } \\
\hline Constant & $1.81 \mathrm{e}-09$ & & & & & & 0.071165 & & \\
\hline $\begin{array}{l}\text { Organizational } \\
\text { Policies }\end{array}$ & 0.1296435 & 0.1157638 & 1.12 & 0.265 & 0.344217 & 2.91 & 0.129644 & & \\
\hline $\begin{array}{l}\text { Organizational } \\
\text { Support }\end{array}$ & 0.209692 & 0.1195309 & 1.75 & 0.082 & 0.35193 & 2.84 & 0.209692 & & \\
\hline $\begin{array}{l}\text { Supervisor`s } \\
\text { Support }\end{array}$ & -0.099294 & 0.0875431 & -1.13 & 0.259 & 0.417679 & 2.39 & -0.09929 & & \\
\hline $\begin{array}{l}\text { Job } \\
\text { Characteristics }\end{array}$ & 0.0915823 & 0.1028627 & 0.89 & 0.375 & 0.4865 & 2.06 & 0.091582 & & \\
\hline $\begin{array}{l}\text { Reward\& } \\
\text { Recognition }\end{array}$ & 0.1337176 & 0.0749008 & 1.79 & 0.077 & 0.509992 & 1.96 & 0.133718 & & \\
\hline $\begin{array}{l}\text { Teamwork\& } \\
\text { Cooperation }\end{array}$ & -0.1010246 & 0.087174 & -1.16 & 0.249 & 0.512939 & 1.95 & -0.10102 & & \\
\hline Feedback & 0.1756643 & 0.1153473 & 1.52 & 0.131 & 0.530589 & 1.88 & 0.175664 & & \\
\hline $\begin{array}{l}\text { Maximizing } \\
\text { Potential }\end{array}$ & 0.2052486 & $0.09918 * *$ & 2.07 & 0.041 & 0.753269 & 1.33 & 0.205249 & & \\
\hline $\begin{array}{l}\text { Retention } \\
\text { Intention }\end{array}$ & -0.1441383 & $0.07006^{* *}$ & -2.06 & 0.042 & 0.887698 & 1.13 & 0.14414 & 0.438 & 13.18 \\
\hline \multicolumn{10}{|c|}{ Dependent Variables $\rightarrow$ Commitment wrt Work $=C_{\text {_Work }}$} \\
\hline Constant & $-4.27 e-08$ & & & & & & 0.07976 & & \\
\hline $\begin{array}{l}\text { Organization } \\
\text { Policies }\end{array}$ & 0.009772 & 0.1331052 & 0.07 & 0.942 & 0.344217 & 2.91 & 0.009733 & & \\
\hline $\begin{array}{l}\text { Organizational } \\
\text { Support }\end{array}$ & -0.089477 & 0.1184603 & -0.76 & 0.452 & 0.351931 & 2.84 & -0.08948 & & \\
\hline $\begin{array}{l}\text { Supervisor`s } \\
\text { Support }\end{array}$ & -0.0992413 & 0.1185257 & -0.84 & 0.404 & 0.417679 & 2.39 & -0.09924 & & \\
\hline $\begin{array}{l}\text { Job } \\
\text { Characteristics }\end{array}$ & 0.215924 & 0.128557 & 1.68 & 0.096 & 0.486500 & 2.06 & 0.215924 & & \\
\hline $\begin{array}{l}\text { Reward\& } \\
\text { Recognition }\end{array}$ & 0.0151483 & 0.0869345 & 0.17 & 0.862 & 0.509992 & 1.96 & 0.015148 & & \\
\hline $\begin{array}{l}\text { Teamwork\& } \\
\text { Cooperation }\end{array}$ & -0.0926919 & 0.0818905 & -1.13 & 0.26 & 0.512939 & 1.95 & -0.09269 & & \\
\hline Feedback & 0.27544 & 0.1424553 & 1.93 & 0.056 & 0.530589 & 1.88 & 0.275449 & & \\
\hline $\begin{array}{l}\text { Maximizing } \\
\text { Potential }\end{array}$ & 0.2137457 & $0.103302 * *$ & 2.07 & 0.041 & 0.753269 & 1.33 & 0.213746 & & \\
\hline $\begin{array}{l}\text { Retention } \\
\text { Intention }\end{array}$ & -0.2493367 & $0.08607 * *$ & -2.9 & 0.005 & 0.887698 & 1.13 & -0.24934 & 0.292 & 5.63 \\
\hline
\end{tabular}

Table-3 represents the result of multiple regression models. It is observed that F-statistics is very high for all the estimated models. Furthermore, the value of adjusted $\mathrm{R}^{2}$ is fairly high for both the models of 
employee commitment. This indicates that all the estimated models are statistically significant with considerably explanatory power. For each of the explanatory variables the tolerance factor is greater than 0.20 (variance inflation factor (VIF) is less than 5) signifies that the estimated models are free from severe multicollinearity problem.

As regard, the individual coefficients, for the commitment with respect to company (organizational commitment), it is observed that while coefficient of organizational support and reward \& recognition are statistically significant at $10 \%$ level that maximizing potential and retention intension are statistically significant at $5 \%$ level. The Beta values of organizational support, reward \& recognition and maximizing potential are found to be positive inferring a favorable influence whereas for retention intention, the value is obtained to be negative, showing an inverse influence.

Similarly for commitment with respect to the work (work commitment), it is observed that coefficient of job characteristics and feedback are statistically significant at $10 \%$ level that maximizing potential and retention intension at $5 \%$ level. The Beta values of job characteristics, feedback and maximizing potential are found to be positive indicating a complimenting influence whereas for retention intension, reciprocal relationship exists.

Therefore from the above analysis, it is clear that not all the predictors of employee satisfaction are contributing towards the overall employee commitment. There are only few predictors which share a significant influence on employee commitment but separately with respect to organization and work. And there is only a single predictor, maximizing potential, which influences the overall employee commitment. Also, retention intention is only predictor which has found to have inverse relationship with the overall employee commitment.

\section{Conclusion \& Discussion}

Out of these nine predictors of employee satisfaction, only few of them possess a significant impact on overall commitment level of employees in the organization. Where, in one hand, the predictors like organizational support and reward \& recognition show greater influence on the 'organizational' part of employee commitment and in other hand, the predictors like job characteristics and feedback have a greater impact on employee commitment for 'work'. The most important factor, retention intension, which involves the behavioral outlook of employees and consider being quite unpredictable, shares a reciprocal relationship with the overall employee commitment level inkling a pitfall to management as it gives a clear indication that the employees are externally oriented for better career advancement and organizational perspective .Management has to step an extra mile to reform its strategies in order to maintain a constant or positive retention intension amongst its employees. Maximizing potential, which includes the training and development aspects, is the only factor that is sub setting both the types of employee commitment-organization as well as work.

On a broader outlook, the study may open a gateway for management towards a new dimension of training and development needs. But, for that, management needs to spend its resources and conduct surveys for identifying the gap areas for employee commitment and types of employee (Ambassador, Career oriented, Company oriented or Uncommitted) it is possessing. Hence, in parallel, their dimensions for training and developmental needs for maximizing potential can also be identified. A well defined training and development program plays a critical part in nurturing employee's psyches. They want to feel that the job they do is important to the success of business and business is investing time and money in them in order to do the job correctly, at higher level.

As discussed earlier, in this regard excluding the two extremes (ambassador and uncommitted employees), those employees who are found to be affiliated more towards organization (termed as company oriented) need training modules which consist of enhancement of their liking towards the type of work they are associated with . From the present study, it may be concluded that modulating the job characteristics and increasing the level of constructive feedback, the commitment level towards their work may be raised hence, balancing the overall level of employee commitment. Communication is one most important aspect as it values the organization and provides everyone with a consistent process to follow and that knowledge can help them confidently to approach situations particularly difficult. Taking regular sessions of one-to-many discussions by top management, encourage generating new ideas and inputs for betterment of work situations may help to elevate their association towards work. By sharing knowledge that is relevant to employee's career aspirations will help them to foresee the betterment in future performance. It also aids in assisting the employee to assess their skills, interests, motivations and areas for improvements.

Similarly, those employees who have higher affiliation towards their work (Career oriented), the level of their organizational commitment can be upgraded by providing strong organizational support. In such case, management should take efforts by providing flexible work arrangements to maintain a steady work-life balance. Introducing such programs and policies that facilitate work-life balance acknowledge that employees have responsibilities and lives outside of work. Also, help individuals better manage these multiple demands leading to higher level of commitment and loyalty towards the organization. Other programs like enhancing 
innovation initiatives in organization culture, which will latterly act as a driving force for not only organizational success but also contributes in building the organizational commitment level. Reward \& recognition, is another predictor which also significantly influences the level of organizational commitment. Hence, a reward system has to be formulated in a way so that it can able to boost up the morale of the existing employees. Employees want to do a good job and enjoy coming to work when they feel their efforts make a difference for the organization. They also enjoy receiving recognition for the contributions they make for organization.

Hence, we identify a need for management to give greater attention on the above cited gap areas regarding employee satisfaction and implementing these discussed gap-specific strategies which in long run may help in setting a balance between different sub-sets of commitment thereby establishing an overall level of employee commitment within the organization.

The present study can also give valuable insight/ for further research to investigate the link between employee commitment and organizational performance.

\section{REFERENCES}

[1.] Naseem A.,Shaik Ejaz S., Malik P.K GPHR (2011), "Impact of Employee Satisfaction on Success of Organization : Relation between Customer Experience and Employee Satisfaction", International Journal of Multidisciplinary Science and Engineering, Vol.2, No.5,pp.41-46

[2.] S.Sengupta, Employee Attrition and Retention: Exploring the Dimensions in the urban centric BPO Industry, doctoral diss., Jaypee Institute of Information Technology, Judge T.A, Watanasbe S. (1994), "Individual Differences in Nature of the Relationship between Job and Life Satisfaction", Journal of Occupational Psychology, Vol. 67, Issue.2, pp.101-107.

[3.] Edgar, F. and Geare, A. (2005), "HRM practice and employee attitude: different measures -different results", Personnel Review, Vol. 34, No. 5, pp. 534- 549.

[4.] Ulrich, Dave, \& Smallwood, Norm, Capitalizing on Capabilities [Electronic version]. Harvard Business Review, June 2004, pp119-127

[5.] W.L French, Human Resource Management ( ${ }^{\text {rd }}$ Edition, Houghton Mifflin, Boston,1994)

[6.] R.T Grant, BSG-620: Human Resources Strategy \& Organizational Structure, Human Resources \& Valuation of Intangible Assets, Patrick Kelsey, Nyack College, Nyack, New 2004. (Dr.) Khan M.M, Zia-ur-Rehman, Muhammad W.A.(2012), “The Impact of Employee Commitment on Employee Satisfaction role of Employee Performance as a Moderating Variable", Singapore Journal of Business Economics and Management Studies, Vol. 1, No.2, pp.68-80.-1INtro

[7.] Sageer A, Rafat S \& Agarwal P. (2012), "Identification of Variables Affecting Employee Satisfaction and Their Impact on the Organization.”, IOSR Journal of Business and Management, Vol.,5 No1. , pp.32-39

[8.] Chen, S.H., Yang, C.C., Shiau, J.Y., and Wang, H.H. (2006), "The development of an employee satisfaction model for higher education", The TQM Magazine, Vol. 18, No. 5, pp.484-500.

[9.] Khanifar H.(2012), "Analysis of Job Satisfaction and Professional Commitment between Staffs." Journal of Basic and Applied Scientific Research, Vol.2, No.7, pp.6424-6429.

[10.] Annamalai T, Abdullah A. G. K and Alazidiyeen N. J4 (2010), "The Relationships between Organizational Justice, Trust and Performance Appraisal in Malaysian Secondary Schools” European Journal of Social Sciences, Vol. 13, No.4,pp. 623-632

[11.] Colaboglu U.,Culha O., Atay H. (2010), "The Effects of Perceive Organizational Support on Employee`s Affective OutcomeEvidence from the Hotel Industry", Tourism and Hospitality Management, Vol. 16,No.2, pp.125-150.

[12.] Dawal S.Z., Taha Z., Ismail Z.,(2009), " Effect of job organization on job satisfaction among shop floor employees in automotive industries in Malaysia.” International Journal of Industrial Ergonomics, Vol. 39 No.1, pp. 1-6.

[13.] Danish R.Q, Usman Ali (2010), "Impact of Rewards and Recognition on Job Satisfaction and Motivation: An Empirical Study from Pakisthan”, International Journal of Business Management, Vol. 5, No. 2, pp. 158-160

[14.] Annamalai T, Abdullah A. G. K and Alazidiyeen N. J4 (2010), “The Relationships between Organizational Justice, Trust and Performance Appraisal in Malaysian Secondary Schools" European Journal of Social Sciences, Vol. 13, No.4,pp. 623-632

[15.] Fried, Y. \& Ferris, G.R. (1987), "The validity of the job characteristics model: A review and meta-analysis", Personnel Psychology, Vol. 40, No. 2, pp. 287-322.

[16.] Kim S. J, Hamner Clay W.(1976), "Effect of performance feedback and goal setting on productivity and satisfaction in an organizational setting" Journal of Applied Psychology, Vol. 61, No. 1,pp. 48-57

[17.] Warsi S, Fatima Noor and Sahibzada Shamim A., (2009), "Study on Relationship Between Organizational Commitment and its Determinants among Private Sector Employees of Pakistan” International Review of Business Research Papers Vol. 5, No. 3, pp. 399- 41

[18.] Vandenberghe Christian and Tremblay Michel, (2008), "The Role of Pay Satisfaction and Organizational Commitment in Turnover Intentions: A Two-Sample Study” Journal of Business Psychology, Vol. 22, No.3, pp275-286.

[19.] Vandenberghe Christian and Tremblay Michel, (2008), "The Role of Pay Satisfaction and Organizational Commitment in Turnover Intentions: A Two-Sample Study" Journal of Business Psychology, Vol. 22, No.3, pp275-286.

[20.] Khanifar H.(2012), "Analysis of Job Satisfaction and Professional Commitment between Staffs." Journal of Basic and Applied Scientific Research, Vol.2, No.7, pp.6424-6429.

[21.] Song Hoon Ji and Kim Min Hon,(2009), "The integrative structure of employee commitment: The influential relations of individuals characteristics in a supportive learning culture”, Leadership \& Organization Development Journal ,Vol. 30, No. 3.,pp. 240-255. 